\title{
THE DIAGNOSTIC VALUE OF ISOLATED URINARY MUCOPOLYSACCHARIDES AND OF LYMPHOCYTE INCLUSIONS IN GARGOYLISM
}

\author{
BY \\ HELEN MUIR, URSULA MITTWOCH and T. BITTER \\ From St. Mary's Hospital, and the Galton Laboratory, University College, London
}

(RECEIVED FOR PUBLICATION NOVEMBER 28, 1962)

Gargoylism or Hurler's syndrome (Hunter, 1917; Hurler, 1919) is a rare genetically determined disease (McKusick, 1960) appearing in autosomal recessive and sex-linked forms. Two of the six known sulphated mucopolysaccharides are produced in excess, namely chondroitin sulphate $B$ and heparitin sulphate. They accumulate in most organs of the body, especially in the liver and the spleen (Meyer, Grumbach, Linker and Hoffman, 1958; Meyer, Hoffman, Linker, Grumbach and Sampson, 1959). They appear as metachromatic deposits which, however, are very soluble in routine fixatives so that liver biopsies might show vacuoles unless they are fixed by special techniques (Haust and Landing, 1961). Both mucopolysaccharides are excreted in large amounts in the urine (Dorfman and Lorincz, 1957; Lorincz, 1958) and being resistant to hyaluronidase, are distinguishable from the mucopolysaccharides of normal urine, which are excreted only in small amounts (Di Ferrante and Rich, 1956).

It has been found that a proportion of the lymphocytes of such patients contains abnormal cytoplasmic inclusions (Mittwoch, 1959, 1961) which can be seen in preparations stained with May-GrunwaldGiemsa. They also stain metachromatically with toluidine blue. These staining reactions agree with the assumption that the inclusions consist of acid mucopolysaccharides. Up to the present the lymphocyte inclusions have been found in a total of 22 patients, in whom a diagnosis of gargoylism had been suggested.

In the present investigation these inclusions have been correlated with the presence of abnormal amounts of hyaluronidase-resistant mucopolysaccharides in the urine. Some of the clinical findings on the patients investigated by both methods are summarized in Table 1 . Table 2 summarizes the clinical findings of the other patients in whom lymphocyte inclusions were found, without biochemical investigation. Reports on some of the cases have already been published: five cases in Table 2 and Case 2 of Tables 1 and 3 (Mittwoch, 1959); Cases 1, 3, 6 and 7 (Mittwoch, 1961).

\section{Methods}

Isolation of Urinary Sulphated Mucopolysaccharides. The urines $(150-2,000 \mathrm{ml}$.) were collected under toluene, adjusted to $p \mathrm{H} 7$ with acetic acid and digested with pancreatin $\left(100 \mathrm{mg} . / 100 \mathrm{ml}\right.$.) for 24 hours at $37^{\circ} \mathrm{C}$. They were then dialysed for three days against distilled water in cellulose tubing (Visking Inc.) that had previously been heated dry at $85^{\circ}-90^{\circ} \mathrm{C}$. to reduce its pore size (Callanan, Carroll and Michell, 1957), and adjusted to $p \mathrm{H} 5$. The sulphated mucopolysaccharides were isolated and purified by precipitating with saturated aqueous 5-aminoacridine hydrochloride and then converting to the sodium salts (Muir, 1958). After repeating this operation, the sodium salts were finally dried over phosphorus pentoxide in vacuo at $60^{\circ} \mathrm{C}$. for 48 hours and weighed. Their uronic acid content was determined by a modification (Bitter and Muir, 1962) of Dische's (1947) carbazole reaction and their hexosamine content by the Elson and Morgan (1933) reaction using the distillation procedure of Cessi and Piliego (1960). The resistance to digestion by testicular hyaluronidase of the isolated urinary mucopolysaccharides was determined by the method of Mathews, Roseman and Dorfman (1951).

Demonstration of Intracellular Lymphocyte Inclusions. All blood films were made from finger pricks using the coverslip method (Wintrobe, 1961). Such preparations were shown to be superior to those made on slides for the preservation of cytological detail, since the leucocytes are less damaged when spread by capillary force (Davidson, 1961). All films were fixed in absolute methanol for at least 10 minutes. Specimens from all patients were stained in a $20 \mathrm{ml}$. specimen jar with: (i) MayGrunwald-Giemsa (air-dried films), and (ii) toluidine blue (air-dried and wet-fixed films). 
TABLE 1

CLINICAL SIGNS OF PATIENTS EXAMINED FOR LYMPHOCYTE INCLUSIONS AND URINARY MUCOPOLYSACCHARIDES

\begin{tabular}{|c|c|c|c|c|c|c|c|c|}
\hline $\begin{array}{c}\text { Case No. } \\
\text { and } \\
\text { Initials }\end{array}$ & Sex & $\underset{\text { (yrs.) }}{\text { Age at }}$ & $\begin{array}{c}\text { Mental } \\
\text { Retardation }\end{array}$ & $\begin{array}{l}\text { Corneal } \\
\text { Opacities }\end{array}$ & $\begin{array}{c}\text { Enlarged } \\
\text { Liver Spleen }\end{array}$ & $\begin{array}{l}\text { Wedge-shaped } \\
\text { Vertebrae } \\
\text { and/or } \\
\text { Kyphosis }\end{array}$ & $\begin{array}{c}\text { Lymphocyte } \\
\text { Inclusion }\end{array}$ & $\begin{array}{l}\text { Abnormal } \\
\text { Mucopoly- } \\
\text { saccharides }\end{array}$ \\
\hline $\begin{aligned} & 1 \text { N.B. } \\
& 2 \text { P.G. } \\
& 3 \text { G.K. } \\
& * 4 \text { C.M. } \\
& \text { *5 D.M. } \\
& 6 \text { M.P. } \\
& 7 \text { D.T. } \\
& 8 \text { M.B. } \\
& 9 \text { A.C. } \\
& 10 \text { A.E. } \\
& 11 \text { M.G. }\end{aligned}$ & $\begin{array}{l}\mathbf{M} \\
\mathbf{M} \\
\mathbf{F} \\
\mathbf{M} \\
\mathbf{M} \\
\mathbf{M} \\
\mathbf{M} \\
\mathbf{M} \\
\mathbf{M} \\
\mathbf{M} \\
\mathbf{M}\end{array}$ & $\begin{array}{c}1 \frac{1}{2} \\
6 \\
5 \\
8 \\
10 \\
12 \\
13 \\
6 \\
3 \\
2 \frac{1}{2} \\
11\end{array}$ & $\begin{array}{c}+ \\
+ \\
+ \\
+ \\
+ \\
\text { Mild } \\
+ \\
\text { Perhaps } \\
+ \\
+ \\
+\end{array}$ & $\begin{array}{l}+ \\
- \\
- \\
- \\
- \\
\overline{N I} \\
- \\
t+\end{array}$ & $\begin{array}{ll}+ & + \\
+ & + \\
+ & + \\
+ & - \\
+ & - \\
+ & + \\
+ & + \\
+ & + \\
+ & + \\
+ & + \\
+ & +\end{array}$ & $\begin{array}{l}\bar{t} \\
+ \\
- \\
\overline{+} \\
+ \\
+ \\
+ \\
+\end{array}$ & $\begin{array}{l}+ \\
+ \\
+ \\
\pm \\
\pm \\
+ \\
+ \\
- \\
- \\
-\end{array}$ & $\begin{array}{l}+ \\
+ \\
+ \\
+ \\
+ \\
+ \\
+ \\
- \\
-\end{array}$ \\
\hline
\end{tabular}

* Brothers.

+ Left corneal haze, possibly caused by inverted eyelashes.

NI Not investigated.

TABLE 2

CLINICAL SIGNS OF PATIENTS EXAMINED FOR LYMPHOCYTE INCLUSIONS ONLY

\begin{tabular}{|c|c|c|c|c|c|c|c|}
\hline Initials & Sex & $\begin{array}{c}\text { Age } \\
\text { (yrs.) }\end{array}$ & $\begin{array}{c}\text { Mental } \\
\text { Retardation }\end{array}$ & $\begin{array}{c}\text { Corneal } \\
\text { Opacities }\end{array}$ & $\underset{\text { Liver }}{\text { Enlarged }} \stackrel{\text { Spleen }}{ }$ & $\begin{array}{l}\text { Wedge-shaped } \\
\text { Vertebrae } \\
\text { and/or Kyphosis }\end{array}$ & $\begin{array}{l}\text { Lymphocyte } \\
\text { Inclusion }\end{array}$ \\
\hline $\begin{array}{l}\text { M.D. } \\
\text { S.G. } \\
\text { W.B. } \\
\text { L.W. } \\
\text { O.C. } \\
\text { G.W. } \\
\text { T.C. } \\
\text { *G.C. } \\
\text { C.N. } \\
\text { K.S. } \\
\text { P.S. } \\
\text { J.R.P. } \\
\text { C.H. } \\
\text { S.B. } \\
\text { †R.H. }\end{array}$ & $\begin{array}{l}\mathbf{M} \\
\mathbf{M} \\
\mathbf{M} \\
\mathbf{F} \\
\mathbf{F} \\
\mathbf{M} \\
\mathbf{M} \\
\mathbf{M} \\
\mathbf{M} \\
\mathbf{F} \\
\mathbf{M} \\
\mathbf{M} \\
\mathbf{M} \\
\mathbf{M} \\
\mathbf{M}\end{array}$ & $\begin{array}{c}15 \\
7 \\
4 \\
7 \\
6 \\
3 \\
4 \\
3 \\
9 \\
15 \text { mths } \\
4 \frac{1}{2} \\
5 \frac{3}{4} \\
6 \frac{1}{2} \\
2 \\
12\end{array}$ & $\begin{array}{l}+ \\
+ \\
+ \\
+ \\
+ \\
+ \\
+ \\
+ \\
+ \\
+ \\
+ \\
+ \\
+ \\
\text { Slight } \\
\text { Slight }\end{array}$ & $\begin{array}{l}- \\
\overline{+} \\
+ \\
\overline{+} \\
\text { NI } \\
\text { NI } \\
\overline{+} \\
\frac{+}{+} \\
+ \\
+\end{array}$ & $\begin{array}{l}+ \\
+ \\
+ \\
+ \\
+ \\
+ \\
+ \\
+ \\
+ \\
+ \\
+ \\
+ \\
+ \\
+\end{array}$ & $\begin{array}{c}\text { NI } \\
\text { Some abnormalities } \\
+ \\
+ \\
+ \\
+ \\
\text { NI } \\
\text { NI } \\
\text { NI } \\
+ \\
+ \\
+ \\
+ \\
+ \\
\text { NI }\end{array}$ & $\begin{array}{l}+ \\
+ \\
+ \\
+ \\
+ \\
+ \\
+ \\
+ \\
+ \\
+ \\
+ \\
+ \\
+\end{array}$ \\
\hline
\end{tabular}

* Brothers.

$\dagger$ Maternal cousin of M.P., No. 6 in Tables 1 and 3.

NI Not investigated.

TABLE 3

URINARY MUCOPOLYSACCHARIDES AND LYMPHOCYTE INCLUSIONS OF PATIENTS WITH CLINICAL SIGNS OF GARGOYLISM AND UNAFFECTED SUBJECTS

\begin{tabular}{|c|c|c|c|c|c|c|}
\hline $\begin{array}{l}\text { Case No. } \\
\text { and } \\
\text { Initials }\end{array}$ & Sex & $\begin{array}{c}\text { Age } \\
\text { (yrs.) }\end{array}$ & $\begin{array}{l}\text { Lymphocytes Con- } \\
\text { taining Inclusions* } \\
(\%)\end{array}$ & $\begin{array}{l}\text { Mucopolysaccharide } \\
\text { Excretion } \\
\text { (mg./l.) }\end{array}$ & $\begin{array}{c}\text { Resistance to } \\
\text { Hyaluronidase } \\
(\%)\end{array}$ & $\begin{array}{l}\text { Uronic Acid/ } \\
\text { Hexosamine Ratio }\end{array}$ \\
\hline $\begin{aligned} \text { Patients: } & \\
1 & \text { N.B. } \\
2 & \text { P.G. } \\
3 & \text { G.K. } \\
4 & \text { C.M. } \\
5 & \text { D.M. } \\
6 & \text { M.P. } \\
7 & \text { D.T. } \\
8 & \text { M.B. } \\
9 & \text { A.C. } \\
10 & \text { A.E. } \\
11 & \text { M.G. }\end{aligned}$ & $\begin{array}{l}\mathbf{M} \\
\mathbf{M} \\
\mathbf{F} \\
\mathbf{M} \\
\mathbf{M} \\
\mathbf{M} \\
\mathbf{M} \\
\mathbf{M} \\
\mathbf{M} \\
\mathbf{M} \\
\mathbf{M}\end{array}$ & $\begin{array}{l}1 \frac{1}{2} \\
6 \\
5 \\
8 \\
10 \\
12 \\
13 \\
6 \\
3 \\
2 \frac{1}{2} \\
11\end{array}$ & $\begin{array}{r}5 \\
17 \\
22 \\
2 \\
2 \\
12 \\
26 \\
0 \\
0 \\
0 \\
0\end{array}$ & $\begin{array}{l}378 \ddagger \\
503 \ddagger \\
576 \ddagger \\
374 * * \\
377^{* *} \\
171 \ddagger \\
389 \ddagger * * \\
17 \cdot 5 \ddagger \\
15 \cdot 5 \S \\
17 \cdot 5 \ddagger \\
12 \cdot 3 \S\end{array}$ & $\begin{array}{r}93 \\
89 \\
60 \\
78 \\
92 \\
89 \\
100 \\
37 \\
23 \\
16 \\
11\end{array}$ & $\begin{array}{c}0 \cdot 882 \\
1 \cdot 324 \\
1 \cdot 09 \\
1 \cdot 02 \\
\text { NI } \\
0 \cdot 943 \\
0 \cdot 983 \\
\text { NI } \\
\text { NI } \\
\text { NI } \\
\text { NI }\end{array}$ \\
\hline $\begin{array}{c}\text { Unaffected Subjects: } \\
\text { Child } \\
\text { Child } \\
\text { Adult }\end{array}$ & $\begin{array}{l}\mathbf{M} \\
\mathbf{M} \\
\mathbf{M}\end{array}$ & $\begin{array}{l}13 \\
10 \\
31\end{array}$ & $\begin{array}{l}\text { NI } \\
\text { NI } \\
\text { NI }\end{array}$ & $\begin{array}{l}14 \cdot 6 \S \\
21 \cdot 2 \ddagger \\
29 \cdot 9 \S^{* *}\end{array}$ & $\begin{array}{l}28 \\
17 \\
20\end{array}$ & $\begin{array}{l}\text { NI } \\
\text { NI } \\
\text { NI }\end{array}$ \\
\hline
\end{tabular}

* Proportion of the lymphocytes examined.

$\dagger$ Albumin turbidity remaining after $1 \mathrm{hr}$. incubation ( $\%$ of control). $\ddagger$ Weight confirmed by analysis for hexosamine content (Cessi and Piliego, 1960).
\& Weight confirmed by analysis for uronic acid content (Bitter and Muir, 1962).

** Corrected for 'normal' creatinine values (Eastham, 1960).

NI Not investigated. 


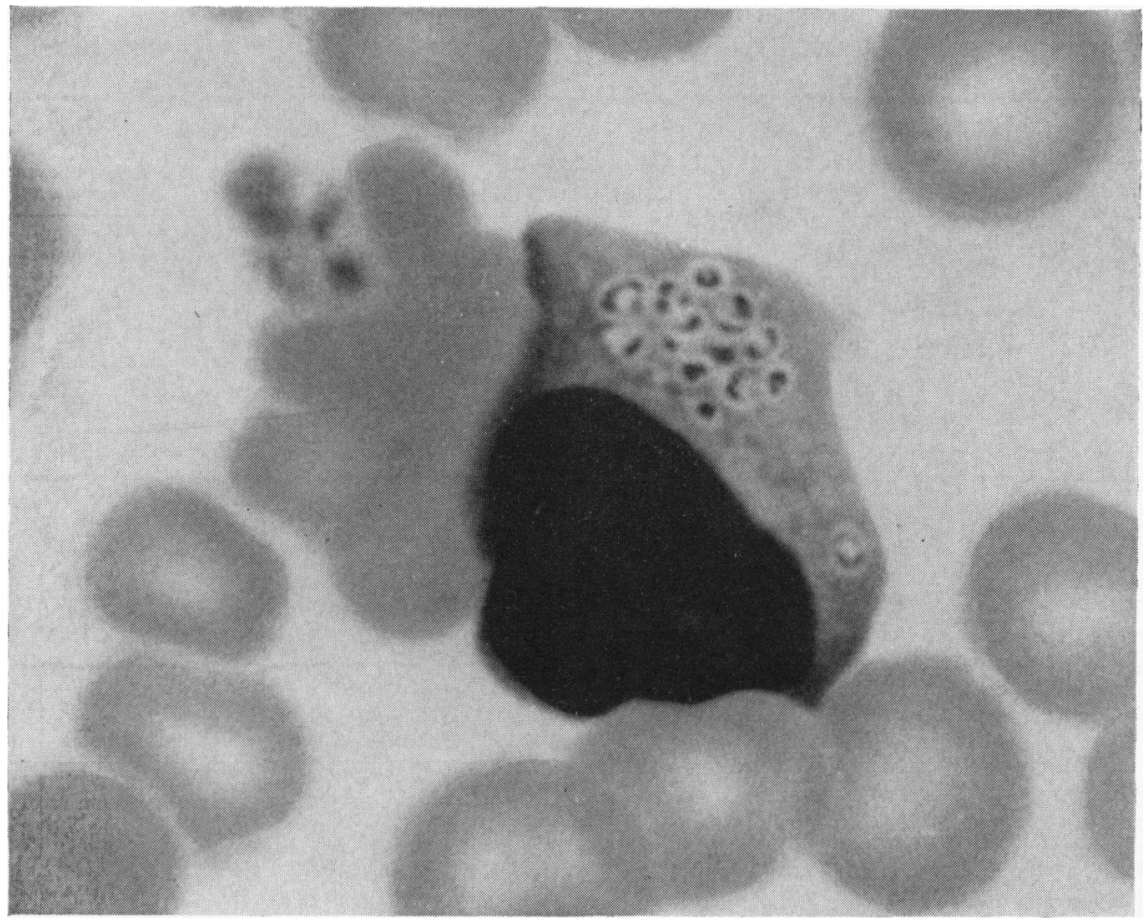

FIG. 1.--Lymphocyte with inclusions. From Brit. J. Haematol. (1959), 5, 365. (Air-dried, May-Grunwald-Giemsa.)

(i) The fixed films were placed in May-GrunwaldGiemsa (Gurr Ltd.) diluted with an equal volume of $1 / 750 \mathrm{M}$ phosphate buffer at $p \mathrm{H} 6.8$ (or 1 buffer tablet pH 6.8 (Gurr Ltd.) per litre). After five minutes this stain was replaced by Gurr's improved Giemsa R 66 diluted 1 in 15 with the $p \mathrm{H} 6.8$ buffer, left for 20 minutes,

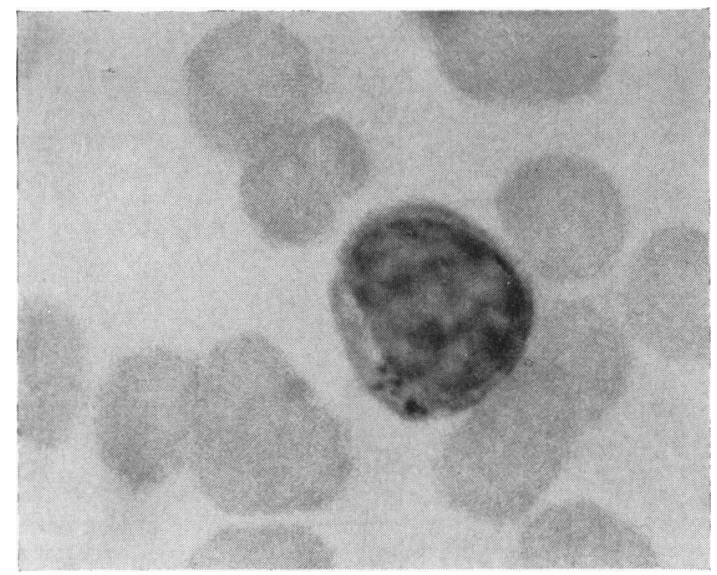

FIG. 2.-Lymphocyte with inclusions. (Air-dried, toluidine blue.) then dehydrated in acetone and xylol and mounted in DPX.

(ii) The fixed films were stained for $\mathbf{3 0}$ minutes in a $0.1 \%$ solution of toluidine blue (Gurr Ltd.) in $30 \%$ methanol, then dehydrated and mounted as in (i).

Both the fixation and the staining must be carried out

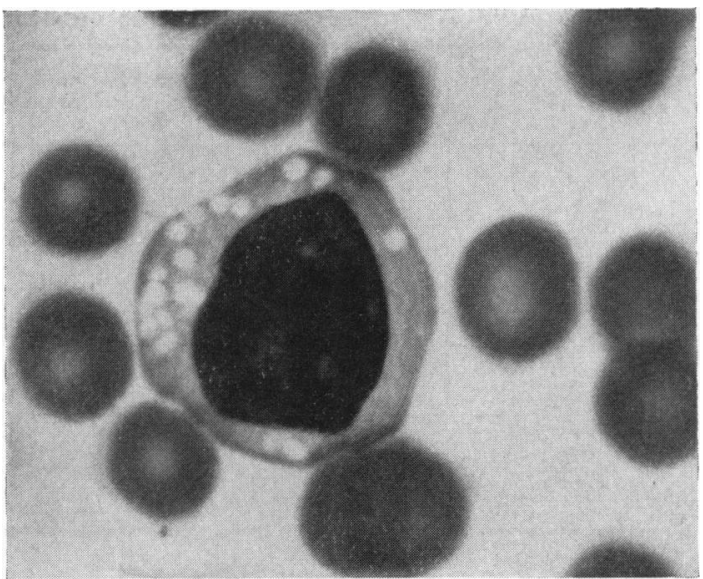

FIG. 3.-Lymphocyte with vacuoles. (Air-dried, May-Grunwald- 
within a few hours of making the blood films. 300 lymphocytes were examined under oil immersion on slides stained both with May-Grunwald-Giemsa and with toluidine blue.

\section{Results}

The results are given in Table 3 . In seven patients (Cases 1-7) who excreted large amounts of hyaluronidase resistant mucopolysaccharides, characteristic inclusions were found in the cytoplasm of a proportion of the lymphocytes.

These inclusions appear typically as deeplystained granules in the centre of vacuoles sharply defined against surrounding cytoplasm. These granules can appear as a dot, a comma or a ring, striking in their hard outline and deep staining. The vacuoles are arranged typically in clusters (Fig. 1). With May-Grunwald-Giemsa, the granules generally appeared red to violet; with toluidine blue they stained metachromatically (Fig. 2) appearing purple against blue cytoplasm and nucleus. The morphology of these inclusions usually distinguishes them from the azurophilic granules of the normal lymphocyte, but the final criterion is their metachromasia with toluidine blue, a stain which does not reveal the azurophilic granules in the cytoplasm. Some lymphocytes had vacuoles (Fig. 3) because the granules in the centre are liable to dissolve during manipulation (Mittwoch, 1960). These vacuolated lymphocytes have no diagnostic value in gargoylism, as it is impossible to distinguish them from those seen in certain pathological conditions, e.g. in amaurotic idiocy, and they may be difficult to delimit against normal vacuoles.

Mucopolysaccharides isolated from the urines of three normal subjects amounted to $12-30 \mathrm{mg}$./l., of which approximately only $20 \%$ was resistant to hyaluronidase. From Cases $1-7,170 \mathrm{mg}$. to $570 \mathrm{mg}$. were recovered per litre of urine, of which 80 to $100 \%$ was resistant to the enzyme. The mucopolysaccharides from Case 3 (G.K.) differed from the others because only $60 \%$ was resistant.

The uronic acid/hexosamine ratio was approximately unity for the mucopolysaccharides of the majority of the patients. Most patients excrete a preponderance of chondroitin sulphate $B$ which contains iduronic acid giving a low carbazole colour yield, but in the modified carbazole reaction used here, the colour yield of iduronic acid is only $17 \%$ lower than that of glucuronic acid.

No hexose was detected by the anthrone method (Trevelyan and Harrison, 1952).

\section{Discussion}

The recessive enchondral dysostoses, such as the Morquio-Brailsford-Ullrich syndrome (reviewed by
Grebe, 1959), gargoylism (reviewed by McKusick, 1960), Ribbing's (1937) epiphysial dysostosis and a number of observations difficult to classify, form a group of diseases with clinical and radiological symptoms overlapping to such an extent that some authors (Eichenberger, 1954; Zellweger, Ponseti, Pedrini, Stamler and von Noorden, 1961) even consider them as one nosological entity. In some, but not in every case, of these diseases, enlarged granules have been found in the polymorphonuclear leucocytes. These granules were first described by Alder (1939) in two sibs who, at puberty, developed meta-epiphysial osteochondronecroses as seen in Ribbing's disease (Alder, 1950). Reilly (1941) described similar granules in four out of eight patients with gargoylism. More recently, such granules were found repeatedly in the MorquioBrailsford-Ullrich syndrome (Eichenberger, 1954; Zellweger et al., 1961). However, these granules are far from being a constant feature (Undritz, 1954) and are not pathognomonic for any single one of these diseases.

In agreement with the findings of Gasser (1950) and other authors, no such abnormal granules ('Reilly bodies') could be found in the polymorphonuclear leucocytes of the 22 cases of gargoylism listed in Tables 1 and 2.

Cells of an induced inflammatory exudate (Carlisle and Good, 1960) show inclusions morphologically similar to those described here. Correlation with other diagnostic tests was satisfactory but not altogether complete (Sanfilippo and Good, 1961).

In the 22 cases of gargoylism examined so far, the lymphocytes of peripheral blood contained characteristic inclusions such as were first described by Gasser (1950) and Gasser and Zellweger (1950) in three patients with gargoylism. Although they did not use toluidine blue, the morphological description agrees with the present findings. Such metachromatic inclusions have so far been reported only in gargoylism.

A high excretion of mucopolysaccharides has been noted in over 80 clinically diagnosed cases whose urines have been examined, with only two probable exceptions (Dorfman, 1958; Sanfilippo and Good, 1961), whereas several hundred children having a variety of other diseases, whose urines were examined at the same time, excreted normal amounts of mucopolysaccharides (reviewed by Muir, 1963). Nevertheless, a moderately high mucopolysaccharide excretion has been noted in Marfan's syndrome (Berenson and Serra, 1959) as well as in children of three families with heritable multiple exostoses, and of one family with arthro- 
osteo-onychodysplasia (Lorincz, 1961). The mucopolysaccharides found to be excreted in these diseases are not resistant to hyaluronidase. A somewhat raised excretion has been noted in some cases of Morquio-Brailsford-Ullrich syndrome (Zellweger et al., 1961; Maroteaux and Lamy, 1961; Dyggve, Melchior and Clausen, 1962; Sanfilippo and Good, 1962). Three cases have been reported to excrete a considerable proportion of keratosulphate (Pedrini, Lennzi and Zambotti, 1962). Although keratosulphate is resistant to hyaluronidase it contains galactose in place of uronic acid and would have given low uronic acid/hexosamine ratios, if it had been present in the isolated sulphated mucopolysaccharides of Cases 1-7. Furthermore, no hexose was detected in these mucopolysaccharides.

The total output of mucopolysaccharides found was higher than that previously recorded. This is probably due to two causes: First, the dialysis tubing used in these experiments had been heated to reduce its permeability. This prevents the loss of approximately $15 \%$ of normal and pathological urinary mucopolysaccharides (Bitter and Ewins, 1963) which are more degraded and polydisperse than mucopolysaccharides extracted from tissues (King, Fielden and Boyce, 1962). Secondly, 5-aminoacridine, which has not previously been applied to urinary mucopolysaccharides, precipitates them almost quantitatively, whereas quaternary ammonium salts, which have been widely used for this purpose (Di Ferrante and Rich, 1956), do not (Muir and Bitter, 1962; King et al., 1962).

The high uronic acid/hexosamine ratio of the mucopolysaccharides from Case 2 (P.G.) suggests that heparitin sulphate is a major component (Cifonelli and Dorfman, 1960). Two cases have so far been reported (Lorincz, 1958; Meyer et al., 1958) in which heparitin sulphate alone was found in the urine. It was suggested that these might belong to a third genetic form (Harris, 1961).

One patient (Case 3, G.K.) had a very high output of mucopolysaccharides, but almost half of it was digested by hyaluronidase. Although no similar case has been recorded, the hyaluronidase test has not been widely applied so that it is not possible to know whether this represents a rare variant of the disease.

In spite of suggestive clinical and radiological features, the diagnosis of gargoylism had to be discarded in Cases 8-11 on biochemical and cytological criteria. One of them (Case 9) has since been diagnosed as a case of severe hypothyroidism.

The metabolic defect remains obscure. No biochemical differences have been found between the sex-linked and the autosomal recessive forms
(Meyer et al., 1958); heterozygotes excrete normal amounts of mucopolysaccharides (Grumbach and Meyer, 1958; Campbell and Fried, 1962). Several explanations have been considered (Meyer and Hoffman, 1961), including a defect in the formation of the protein moiety with which chondroitin sulphate $B$ and heparitin sulphate are probably combined in normal tissue, resulting in a compensating overproduction of both compounds. The ease with which most of the abnormal metachromatic material in the tissues dissolves in aqueous fixatives would suggest that these mucopolysaccharides are not combined with protein in the deposits.

However ill defined clinically, gargoylism seems to be distinct among the other recessive enchondral dysostoses by the accumulation of these two chemically defined compounds, and by the high incidence of cardiovascular and cerebral involvement (Burke, 1962).

\section{Summary}

A comparison has been made between the abnormal urinary mucopolysaccharide excretion and intracellular metachromatic lymphocyte inclusions in 11 patients with suggestive clinical and radiological symptoms of gargoylism. Seven patients excreted abnormal amounts of hyaluronidase-resistant sulphated mucopolysaccharides. All these patients had metachromatic inclusions in a proportion of their lymphocytes. The mucopolysaccharide excretion of the four remaining patients was both qualitatively and quantitatively similar to that of the normal subjects tested. No inclusions were found in the lymphocytes of these patients. A diagnosis of gargoylism had therefore to be discarded.

The metachromatic lymphocyte inclusions seem to offer a diagnostic test which so far has been completely confirmed by the biochemical findings of abnormal urinary sulphated mucopolysaccharides.

We are grateful to the following clinicians for their co-operation: Dr. R. E. Bonham Carter, Dr. H. E. Coll, Dr. J. B. Enticknap, Dr. O. P. Gray, Dr. B. H. Kirman, Dr. G. S. Mansell, Dr. D. Morris, Dr. T. E. Oppé, Dr. D. L. Pedersen, Dr. B. W. Richards, Dr. B. E. Schlesinger, Dr. Jean Smellie, Dr. D. H. R. Thomas and Dr. J. P. M. Tizard.

We also thank Miss Linda Gorman and Mr. R. Ewins for technical assistance.

\section{REFERENCES}

Alder, A. (1939). Über konstitutionell bedingte Granulationsveränderungen der Leukozyten. Dtsch. Arch. klin. Med., $183,372$.

183, 1950$)$. Konstitutionel bedingte Granulationsveränderungen der Leukozyten und Knochenveränderungen. Schweiz. med. der Leukozyten
Ws ., 80, 1095 .

Berenson, G. S. and Serra, M. T. (1959). Mucopolysaccharides in urine from patients with Marfan's syndrome. Fed. Proc., $18,190$. 
Bitter, T. and Ewins, R. (1963). A rapid dialysis of multiple samples. Lab. Pract. In the press.

and Muir, H. M. (1962). A modified uronic acid carbazole reaction. ibid., 4, 330 .

reaction. ${ }^{i b i d ., 4}$, 330 .
Burke, E. C. (1962). The clinical spectrum of gargoylism. Proc. Mayo Clin., 37, 241.

Callanan, M. J., Carroll, W. R. and Michell, E. R. (1957). Physical and chemical properties of protamine from the sperm of the salmon (Oncorrhyncus Tschawytscha). 1. Preparation and characterization. J. biol. Chem., 229, 279.

Campbell, T. N. and Fried, M. (1962). Urinary mucopolysaccharide excretion in the sex-linked form of the Hurler syndrome. Proc. Soc. exp. Biol. (N.Y.), 108, 529.

Carlisle, J. W. and Good, R. A. (1960). The inflammatory cycle. A method of study in Hurler's disease. A.M.A. Amer. J. Dis. Child., 99, 193.

Cessi, C. and Piliego, F. (1960). The determination of amino sugars in the presence of amino acids and glucose. Biochem. J., $77,508$.

Cifonelli, J. A. and Dorfman, A. (1960). Properties of heparin monosulfate. J. biol. Chem., 235, 3283.

Davidson, W. M. (1961). Das Kerngeschlecht der Leukozyten. In Die Intersexualitat, ed. C. Overzier. Thieme, Stuttgart.

In Die Intersexualitat, ed. C. Overzier. Thieme, Stuttgart.
Di Ferrante, N. and Rich, C. (1956). The determination of acid amino-polysaccharide in urine. J. Lab. clin. Med., 48, 491.

Dische, Z. (1947). A new specific color reaction of hexuronic acids. J. biol. Chem., 167, 189.

Dorfman, A. (1958). Studies on the biochemistry of connective tissue. Pediatrics, 22, 576.

- and Lorincz, A. E. (1957). Occurrence of urinary acid mucopolysaccharides in the Hurler syndrome. Proc. nat. Acad. Sci. (Wash.), 43, 443.

Dyggve, H. V., Melchior, J. C. and Clausen, J. (1962). MorquioUllrich's disease; An inborn error of metabolism? Arch. Dis. Childh., 37, 525.

Eastham, R. D. (1960). Biochemical Values in Clinical Medicine. Wright, Bristol.

Eichenberger, K. (1954). Kann die Dysostosis Morquio als selbstständiges Krankheitsbild vom Gargoylismus abgetrennt werden. Ann. paediat., 182, 107.

Elson, L. and Morgan, W. T. J. (1933). A colorimetric method for the determination of glucosamine and chondrosamine. Biochem. J., 27,1824 .

Gasser, C. (1950). Contribution to discussion on Alder (1950). Schweiz. med. Wschr., 80, 1097.

- and Zellweger, H. (1950). Abnormal granulation (storage?) in the cells of blood and of various organs in dysostosis multiplex Pfaundler-Hurler. Trans. 6th Intern. Congr. Paediat., Zurich, exhibit 177

Grebe, H. (1959). Erblicher Zwergwuchs. Ergebn. inn. Med. Kinderheilk., 12, 343 .

Grumbach, M. M. and Meyer, K. (1958). Urinary excretion and tissue storage of sulfated mucopolysaccharides in Hurler's tissue storage of sulfated mucopolysaccharides
syndrome. A.M.A. Amer. J. Dis. Child., 96, 467.

Harris, R. C. (1961). Muconolysaccharide disorder. A possible new genotype of Hurler's syndrome. Amer. J. Dis. Child., 102, 741.

Haust, M. D. and Landing, B. H. (1961). Histochemical studies on Hurler's disease: A new method for localisation of acid mucopolysaccharides. J. Histochem. Cytochem., 9, 79.
Hunter, C. (1917). A rare disease in two brothers. Proc. roy. Soc. Med., 10,104 .

Hurler, G. (1919). Uber einen Typ mult ipler Abartungen, vorwiegend am Skelettsystem. Z. Kinderheilk., 24, 220.

King, S. J., Fielden, M. L. and Boyce, W. H. (1962). Acid mucopolysaccharide in normal urine. Clin. chim. Acta, 7, 301

Lorincz, A. E. (1958). Acid mucopolysaccharides in the Hurler syndrome. Fed. Proc., 17, 266.

(1961). Heritable disorders of acid mucopolysaccharide metabolism in humans and snorter dwarf cattle. Ann. N.Y. Acad. Sci. 91, 644.

McKusick, V. A. (1960). Heritable Disorders of Connective Tissue, 2nd ed. Mosby, St. Louis.

Maroteaux, P. and Lamy, M. (1961). Opacités cornéennes et troubles métaboliques dans la maladie de Morquio. Rev. francs. Étud. clin. biol., 6, 481 .

Mathews, M. B., Roseman, S. and Dorfman, A. (1951). Determination of the chondroitinase activity of bovine testicular preparations. J. biol. Chem., 188, 327.

Meyer, K., Grumbach, M. M., Linker, A. and Hoffman, P. (1958). Excretion of sulfated mucopolysaccharides in gargoylism (Hurler's syndrome). Proc. Soc. exp. Biol. (N.Y.), 97, 275. (Hurler's syndrome). Proc. Soc. exp; Biol. (N.Y.), 97, 275. and Rheum., 4, 552.

Rheum., 4, 552. (1959). Sulfated mucopolysaccharides of urine and organs in gargoylism. Proc. Soc. exp. Biol. (N.Y.), 102, 587.

Mittwoch, U. (1959). Abnormal lymphocytes in gargoylism. Brit. J. Haemat., 5, 365.

(1960). Factors influencing the stainability of the lymphocytic inclusions in gargoylism. Proc. 7th Cong. europ. Soc. Haemat., London, Part II, p. 369.

- (1961). Inclusions of mucopolysaccharide in the lymphocytes of patients with gargoylism. Nature (Lond.), 191, 1315.

Muir, H. (1958). The nature of the link between protein and carbohydrate of a chondroit in sulphate complex from hyaline cartilage. Biochem. J., 69, 195.

(1963). The Aminosugars, ed. R. W. Jeanloz and E. A. Balacz, Vol. II, Chapter 24. Academic Press, New York. In the press.

- and Bitter, T. (1962). Unpublished observations.

Pedrini, V., Lennzi, L. and Zambotti, V. (1962). Isolation and identification of keratosulfate in urine of patients affected by Morquio-Ullirich disease. Proc. Soc. exp. Biol. (N.Y.), 110, 847.

Reilly, W. A. (1941). The granules in the leukocytes in gargoylism. Amer. J. Dis. Child., 62, 489.

Ribbing, S. (1937). Studien über hereditäre multiple Epiphysenstörungen. Acta radiol., Suppl. 34.

Sanfilippo, S. J. and Good, R. A. (1961). A laboratory study of the Hurler syndrome. Amer. J. Dis. Child., 102, 766. Hurler syndrome. Amer. Ocid mucopolysaccharides (AMP) in the Hurler syndrome and Morquio's disease. J. Pediat., 61, 296.

Trevelyan, W. E. and Harrison, J. S. (1952). Studies on yeast metabolism. I. Fractionation and microdetermination of cell carbohydrates. Biochem. J., 50, 298.

Undritz, E. (1954). Les malformations héréditaires des elements figurés du sang. Sang, 25, 296.

Wintrobe, M. M. (1961). Clinical Hematology, 5th ed. Lea and Febiger, New York.

Zellweger, H., Ponseti, I. V., Pedrini, V., Stamler, F. S. and von Noorden, G. K. (1961). Morquio-Uilirich's disease. Report of 2 cases. J. Pediat., 59, 549. 